\title{
KOVÁCS Gábor
}

Pannon Egyetem, Modern Filológiai és Társadalomtudományi Kar Irodalom- és Kultúratudományi Intézeti Tanszék

Veszprém, Magyarország

kovacsgabesz1@gmail.com

\section{EGY KÉNYSZERHELYZET VARIÁCIÓI ${ }^{1}$ Gárdonyi Géza: Ábel és Eszter}

\author{
Variations on a boundary situation \\ Géza Gárdonyi: Ábel és Eszter
}

\author{
Varijacije prinudnog stanja \\ Geza Gardonji: Avelj i Estera
}

Gárdonyi 1910-es években megújuló prózaművészetének egyik alaptétele: „,ha azzal ülsz az íróasztalhoz, hogy regényt írsz, kezdd azon, hogy csak tizedrésznyire rövidített, egyjelenetes nagynovellának írod meg”, ,a regényt ne regénynek szándékold, hanem csak novellának” (Gárdonyi 1974, 70). Ennek a jelenetnek pedig feszültségtelinek kell lennie: ,,az izgalmat keresd, amelyben a karakter előötlik. Bajt, szorultságot és a karaktert tengelyében bántó helyzetet, esetet" (Gárdonyi 1974, 77). Az íróra jellemző kisregényforma a novellai prózanyelv sürítő eljárásaival megalkotott kényszerhelyzetből bont ki egy szöveget úgy, hogy elöállítja a szituációhoz vezető előzményeket és az azt levezető következményeket. Az 1905-ös Ábel és Eszter írása során már felismerte Gárdonyi ennek a technikának a termékenységét, de még máshogy alkalmazta. Elemzésemben azt vizsgálom, milyen szövegvilág alakul ki, és milyen egzisztenciális értelem tárul fel akkor, ha egy egész mủvet egyetlen kényszerhelyzet variációs ismétlődései határozzák meg.

Kulcsszavak: határhelyzet, a narráció ritmusa, alakmás, prózanyelvi jelentésújítás

\footnotetext{
${ }^{1}$ A tanulmány az NKFIH által támogatott NN_17 125791 nyilvántartási számú és $A$ kánonképzödés folyamatai komparativ megközelitésben: közép-európai és kelet-közép-európai kánonok a modernség kontextusaiban címú csoportos kutatás, illetve a Bolyai János Kutatási Ösztöndíj (és az ÚNKP Bolyai+) keretében megvalósuló Gárdonyi Géza prózapoétikái címü önálló kutatás eredménye.
} 
„És ismét folytatódott az epedés végtelen éneke.” Ábel és Eszter (Gárdonyi 1962, 106.)

Az Ábel és Eszter című Gárdonyi-regény kiadástörténetének az interpretáció szempontjából jelentős filológiai sajátossága egyfelől az, hogy 1905-ben folytatásokban jelent meg az Új Idők folyóiratban, másfelől pedig, hogy a szerző olyan bevezető és lezáró részeket írt hozzá a kiadó és az olvasóközönség kedvéért a mühöz könyvformátumban történő publikálása során, amelyek eltérítik a szöveget alapvető konstrukciós elvétöl. Mindezt így foglalja össze a regény kiadását kritikai elvekkel végrehajtó Z. Szalai Sándor:

A regény különböző kiadásainak vizsgálata azt mutatja, hogy Gárdonyi írói szándékai nem teljesen feleltek meg a korabeli közönség igényeinek, pontosabban - kiadója sugallatára - Gárdonyi engedett eredeti elképzeléséből. A kisregényt ugyanis az Új Idők közölte először folytatásokban, 1905-ben. [...] A regény a folytatások során mindig poentírozott helyen szakadt félbe, és így végződött: „Eszter - könyörgött [Ábel] -, Eszterkém! De az ajtó be volt már zárva.” A szerelmesek tehát nem lettek egymásé, véget ért a történet a beteljesedés elött.

Az Új Idők olvasói nem tudták elviselni Ábel és Eszter tragikus elválását. Gárdonyi életrajz-írója szerint a regény „befejezőjét” - Ábel és Eszter találkozását öregségükben - az olvasók követelték, kényszerítették ki. Halomszámra érkeztek a levelek a regényt közreadó szerkesztőségbe és Gárdonyi címére a feltett kérdéssel: „Miért nem lettek egymáséi?” S ha az olvasók követeléséhez még hozzátesszük, hogy a regény könyv alakban 1907-ben, a Singer és Wolfner Rt. kiadásában jelent meg, akkor érthetö, hogy Gárdonyi miért toldotta meg később a történetet két fejezettel. Úgy gondoljuk, hogy Gárdonyi müvészetének megértő tiszteletéből egyenesen következik a happy end nélküli, eredeti közlés megörzése jelen kiadásunkban is, mert ez felel meg az író szándékainak. A regény szövegének még egy torzulására kell figyelmeztetnünk az olvasót: a közkézen forgó kiadásokban, például a Dante sorozatában, előszó is található, nevezetesen Ábel és Eszter budai sírfeliratáról, amelyben még ezt adják hírül a „nyájasabb” olvasónak: „Nem keresi azt a sírt soha senki. Legfeljebb, ha egy-egy fülemüle száll reá a nyáréji hónapokban, s danol egyet. Ez a könyv meg annak a dalnak a szövegét mondja el." Nem véletlen, hogy a „prológ” Gárdonyi életében soha nem jelent meg. A papírszeletkéken talált szöveget - saját bevallása szerint - fia, Gárdonyi József rakosgatta, illesztgette össze, „mint a gyermekkéz a kockajátékot”, s ezért tekintettünk el az előszó feltámasztásától (Z. Szalai 1962, 482-483). 
Gárdonyi József ,idegcsillapítónak” (Gárdonyi 1934, 136) nevezi azokat a kezdő és befejező részeket, amelyek a szövegkiadás problematikus részét képezik, s hozzáteszi, hogy ezek a mondatok és bekezdések a könyv keletkezését, ihletettségét teszik érthetővé:

A szerző regénye keletkezéséről a könyve megjelenésekor ezt írta egy napilapba:

„A kilencvenes évek elején olvastam egy hírt arról, hogy Pesten egy agg nő férjhez ment egy agg emberhez. Arra gondoltam, hogy az esküvőjükön mindenki gúnyosan mosolygott.

Én azonban éreztem, hogy ez nem mosolyogni való történet.

Cédulára jegyeztem.

1905-ben fogtam bele, hogy megírjam az előzményeket.

Nem volt nehéz kitalálnom, hogy bizonyára még fiatal szívvel szerették egymást, de mindig gátolta őket valami..." (Gárdonyi 1934, 133-134.)

Az író nagy mennyiségủ stilisztikai javítása és nem feltétlenül szükséges utólagos hozzátoldásai, Gárdonyi József nyilvánvalóan „erőszakos” (bár logikusan megmagyarázott, és az író jegyzeteire támaszkodó) szövegátalakításai, illetve Z. Szalai Sándor teljesen jogos kifogásai ellenére mégiscsak érdemes elolvasni a Singer és Wolfner vagy a Dante Kiadó verzióját, s különösen az előszót, illetve a regényhez hozzátoldott 16 . és 17 . fejezetet, mert bár ténylegesen egyfajta „,idegcsillapítóként” fogják vissza, sőt, talán - valóban - tönkre is teszik a szöveget éltető alapfeszültséget, mégis - túl az ihlet feltárásán is elárulnak valamit arról a szerkezeti mechanizmusról, amely a regény poétikáját meghatározza.

A regény „eredetileg” teljesen nyitott módon végződik vagy inkább szakad meg. Majdnem hét év telik el úgy, hogy a két főszereplő számtalan szituáció által kiterjesztett egyetlen határhelyzetet (vö. Jaspers 2008, 109-143) kénytelen megélni: szeretik egymást, de nem lehetnek együtt, mert mindig közéjük áll valami. Végül egy kisebb vita eredményeként Eszter becsapja az ajtót Ábel orra elött - ezzel „záródik” a regény. Az olvasónak sejtelme sem lehet, hogy pontosan hogyan folytatódik a történet, miközben a már elolvasottak alapján tisztán tudja, hogy a cselekményt a végtelenségig lehetne folytatni hasonló szituációk egymás után helyezésével. A hozzátoldott 16. fejezet azonban így folytatja a történetet:

Ábel darabig csak bámulta a kilincset. Végre is megboszankodott, haza lódult. 
Életében először történt, hogy megharagudott Eszterre, s haragudott reá szivének legérzékenyebb vonaglásával.

- Ő nem hagyta el énértem az urát, én meg hagyjam el most a gyermekemet, a feleségemet! Ő tisztességes volt akkor. Én nem vagyok tisztességes, hanem poltron! Micsoda maga-szereti bestia az asszony!

$\mathrm{S}$ vörösen duzzadozott a képe a haragtól.

- Punktum! Vége! Többet nem lépem át a küszöbét!

Aztán arra gondolt, hogy értelmes embernek nem szabad haragudnia. Mindig az állati részünk haragszik, mikor haragszunk. Minél okosabb valami, annál ritkábban haragszik. S ha volna olyan okos ember, akinél okosabb már senkise lehetne, az olyan ember nem haragudna soha.

\section{- Gondolkodjunk csak nyugodtan!}

És akkor arra emlékezett, hogy hányszor pattant már így Eszter a szeme közé! Eszternek ilyen a természete. Felforr egy-két percre, aztán meg lehiggad, s bánkódik. Azóta bizonyára megnyílott már az ajtó, s Eszter kinézett rajta könnyes szemmel. Bizonyos hogy kinézett, és bánatosan rebegte a leánykájának:

- Elment már Ábel bácsi?

De hogyan van az, hogy ő máskor mindig nyugodt birt maradni az ilyen apró zivatarokban, most meg - életében elöször, - maga is felháborodik és haragszik Eszterre!? (Gárdonyi é. n., 187.)

$\mathrm{Az}$ „elrontott” folytatás egyfelöl rámutat arra, hogy a regény alapstruktúrája nem más, mint egyetlen határhelyzet variációs ismétlődése. Az ,és akkor arra emlékezett, hogy hányszor pattant már így Eszter a szeme közé” mondat pontosan tárja fel, hogy a regény korábbi tizenöt fejezete a „hányszor?” kérdésre adott válasz(ok)ból áll. Vagyis az elbeszélés nem tesz mást, mint hogy előadja azokat a szituációkat, amikor kipattan valamilyen feszültség a két főszereplö között. Másfelől arra is rámutat a 16. fejezet elejének szövege, hogy a figurák hogyan vesznek részt tetteikkel a feszült szituációkban: Ábel a „,gondolkodjunk csak nyugodtan!" mondat és világszemlélet perszonifikációja; Eszter pedig a „felforr egy-két percre, aztán meg lehiggad, s bánkódik” viselkedésmódot testesíti meg. (Ezek azok a föszereplöi cselekvésprogramok, amiket részben elhibáz a 16. [itt Ábel elkezd bosszankodni] és a 17. [itt Eszter válik teljesen kiegyensúlyozottá] fejezet, mert a figurák megváltoztatásával új mércét vezet be abba a regénybe, amelyben a megelőző 15 fejezetre nem volt jellemző a szereplők ,jellemfejlődése” vagy gyökeres átalakulása.)

Legalább annyira jelentôs a 17 . fejezet utolsó mondatainak interpretációs értéke, mint a 16. fejezet első mondataié. A fejezetben az öreg Ábel és az 
öreg Eszter (mindketten özvegyek és gyermekeiket is elvesztették) véletlenül összetalálkozik ugyanazon az útvonalon, mint az első fejezetben: a Lánchídtól a Városligetig vezetó úton, csak most már nem egy omnibuszon, hanem egy villamoson ülve. Majd pedig együtt sétálgatnak: Ábel „élete őszén újra együtt sétál azzal a nővel, aki csak emlék volt már neki” (Gárdonyi é. n., 194). Egy közösen elköltött ebéd közben mindketten röviden elmondják szomorúra fordult életüket, s megegyeznek, hogy másnap is találkoznak, és egy meghatározott útirányt kijelölve elmennek kocsikázni:

Oda gondoltam, ahol elöször beszéltünk... Nem tudom áll-e még az a kis villa ott az út mellett?

- Bizonyosan. No ez kedves gondolat Eszter. Visszaérezzük magunkat a multba Eszterkém.

- És ha még ott az a szikla...

- Együtt nézzük ismét Eszterkém a nap fölkeltét. Ámbátor...

Eszter szomorún mosolygott:

- A nap nyugvását édes Ábelkám (Gárdonyi é. n., 202).

Az idézett mondatok pontosan világítanak rá arra, hogy a történetet alkotó szituációkban egytől egyig egyetlen dologra törekszik a két föszereplő: hogyan lehetne újraalkotni azt a régi pillanatot, amikor egymásba szerettek. Az egész mủ során azt az elmúlt élményt próbálják visszahozni, amikor egy együtt végigsétált holdfényes este után egy sziklánál megpihenve Ábel meghatottan figyelte, Eszter hogyan néz a felkelő napba.

A hold elhalványult. Az éghatár világosodott.

- Szent Isten - mondotta Eszter, - ránk virrad!

- Ne várjuk meg a napkeltét? - kérdezte Ábel.

- A napkeltét? Ez pompás gondolat! Tudod, hogy én még sose láttam a napot fölkelni?

- Annál szebb látvány pedig nincsen, azaz hogy van.

- Micsoda?

- Te magad, édes.

Eszter elmosolyodott.

- Menjünk föl a sziklára.

És fölmásztak a sziklára. Ábel elől. Eszter utána, Ábel kezétől segítve. És nézték, miként piroslik az ég, miként villan föl az első sugár.

De Ábel most is csak Eszter arcát nézte. Amint rásütött a nap, narancsszínű fénnyel öntötte el az arcát, és a fehér kásmirkendőt. A kezében a 
liliom is olyan volt, mintha arannyá változott volna. És a leány szemében is mintha két kis szikra égne.

- Sohse láttam ennél szebbet! - mondotta a leány a napra hunyorogva.

- Én se! - felelte a fiú a leányt bámulva (Gárdonyi 1962, 32-33).

Így tehát a 17. fejezet utolsó szavai (is) felhívják a figyelmet a regény elejére, illetve arra, hogy a mü során a két főszereplö története a napfelkelte által beragyogott szerelmes pillanat emlékének a történetévé válik.

Amint látjuk tehát, a regényhez „hozzáírt” 16. és 17. fejezet nem annyira folytatja, mint inkább interpretálja a szöveget. Szövegbelső önértelmezéssé formálódik az „új” befejezés, amely nem is annyira történetmondó, inkább önreferenciális funkcióval bír. Azonban a 16. és a 17. fejezet ismerete nélkül is felismerhetjük, hogy (1) a regény mindenekelött a szerelem emléke által szervezett történetet épít fel úgy, hogy (2) ismétlődő módon olyan szituációkat helyez egymás után, amelyekben az emlék visszahozhatatlansága mutatkozik meg eltérő variációkban, s amely szituációkra (3) a két főszereplő mindig ugyanazon cselekvésprogrammal reagál (Ábel: ,gondolkodjunk csak nyugodtan!”, Eszter: „felforr egy-két percre, aztán meg lehiggad, s bánkódik”). A két fejezet csak (újra) megerősíti a szöveg által a korábbi fejezetekben már feltárt mechanizmust. Az alábbi értelmezés során azt vizsgálom, hogy milyen narratív és textuális eljárásokkal dolgozik az a szövegkonfiguráció, amely szituációs variánsokkal terjeszt ki regénnyé egyetlen alaphatárhelyzetet.

A regény részletes tárgyalása előtt azonban tegyünk egy kisebb kitérőt, $\mathrm{s}$ vessünk egy pillantást a szöveghez utólagosan hozzátoldott előszóra is:

Fehér sírkő a budai temetőben. A névirat rajta csak ennyi:

Ábel és Eszter.

Semmi egyéb.

Megérthetö, hogy a követ még életükben faragtatták az alatta nyugovók. S akik eltemették öket, nem gondoltak vele, hogy az évszámot is odavéssék a kőre.

Minek is? Nem keresi azt a sírt soha senki. Legfeljebb ha egy-egy fülemüle száll reá a nyárelei hónapokban, s danol egyet.

Ez a könyv meg annak a dalnak a szövegét mondja el (Gárdonyi é. n., 1).

Az elöszó is interpretációs értékkel, önreferenciális funkcióval bír. S nem is annyira a történet, mint inkább a szöveg szempontjából. Vajon mit is sugall az, hogy „,a könyv annak a dalnak a szövegét mondja el”, amit a sírra szálló fülemüle énekel? Hogy értsük azt, hogy a regény egy dal hült helyén áll? Hogyan 
képes egy olvasható könyv egy hallható éneket pótolni? Hogyan lehet egy prózamü egy sohasem létezett versszöveg rekonstrukciója?

\section{Versstruktúrára írt prózaszöveg}

Az Ábel és Eszter regényhez hozzátoldott előszónak az utolsó mondata (,ez a könyv meg annak a dalnak a szövegét mondja el") megismétli a szöveg egy másik kifejezését: ,és ismét folytatódott az epedés végtelen éneke" (Gárdonyi 1962, 106). Ez utóbbi mondat arra hívja fel a figyelmünket, hogy a regény konstrukciós elve egy olyan (nem létező) vers strukturális sajátosságaira épül és emlékeztet, amelynek ritmikus ismétlődésrendszere a végtelenségig folytatható: létezik egy ritmusséma, amelyet határok nélkül lehet folytatni és kitölteni nyelvi anyaggal, szavakkal, történésekkel. Mielőtt tehát megvizsgálnánk, milyen az a prózaszöveg, amely elö képes adni egy ilyen nem létező vers születését, kibomlását és történetét, érdemes körüljárni, hogyan lehet elképzelni ezt a verset.

Talán nem túlzás azt állítani, hogy Puskin híres Szerettem Önt... kezdetủ 1829-es költeménye gyökeresen megváltoztatta a szerelmi líra nyelvét.

Szerettelek! S szerelmem lángja

Szívemben tán még most is éget.

De fö elöttem nyugodalmad:

Meg nem zavarlak soha téged.

Szerettelek! hajh, néma fájdalommal,

Kínok martalékául vetve;

Oly hön, oly igazán szerettelek...

Bár valaha más úgy szeretne!

Zilahy Imre forditása

(Puskin 1866, 365.)
Szerettem Önt: talán e mély szerelem

A lelkemben nem hunyt egészen el;

De békéjét ne dúlja már fel ez sem;

Nem is búsítom önt már semmivel.

Szerettem önt, némán, reményvesztetten, Voltam szelíd, majd féltékeny s irigy Mély áhítattal, gyöngéden szerettem, Ég adja, hogy szeresse más is így.

Franyó Zoltán fordítása (Puskin 1964, 208.)

Ez a vers tartalmában és formájában is valami olyasmit állít elő, amely segít megérteni Ábel és Eszter „énekét”. A Puskin-vers (tartalmában) egyszerre lehet Ábel szólamának és Eszter szólamának sűrítése. A regény kiinduló és az egész művet meghatározó határhelyzete az, hogy már az első pillanattól kezdve világos: az egymásra rátaláló főszereplők nem maradhatnak együtt, mert egy régebbi családi szerződés elkötelezte Esztert egy másik férfihoz. A szöveg olyan szituációkat sorol egymás után, amelyekben a két föszereplö lopott pillanatokban együtt beszélget, de minden együttlétet beárnyékol „egy ösmeretlen ember réme" (Gárdonyi 1962, 23), egy harmadik személy (Eszter elhunyt apja, gondoskodó anyja, jegyese, majd férje, anyósa és anyósának 
húga, kislánya, majd Ábel felesége, kisfia stb.), aki állandóan arra emlékezteti öket, hogy „közénk mindig új falakat épít a sors” (Gárdonyi 1962, 84). Nem nagyon tehetnek mást, mint hogy reményvesztetten megadják magukat ennek a határhelyzetnek, amelyből kilépni nem lehet: továbbra is szelíden szeretik egymást, s közben olykor féltékenyen és irigykedve, de azt kívánják, hogy a másik szenvedését váltsa fel egy harmadik ember szeretete. Puskin verse tartalmilag ugyanezt a regénnyé kibontható diszpozíciót süríti össze nyolc sorba.

De ennél talán még izgalmasabb a Puskin-vers szerkezeti felépítése, amely ugyancsak szoros összefüggésbe állítható a Gárdonyi-regény konstrukciós elvével. A költemény egyik líratörténetileg kiemelkedő jelentősége a trópusok hiányában rejlik: ,,valóban, szókészletében egyetlen valóságos szókép sincs, a megkövesedett, köznapi szóhasználatba került metafora - a szerelem kihunyt természetesen itt nem jön számításba" (Jakobson 1968, 268). Így a vers a költői jelentést nem a trópusok metaforikus szemantikájával, hanem a versmondatok grammatikai és ritmikai paralelizmusai által létesített figurális jelentéssel teremti meg. Jakobson híres elemzésében részletesen írja le azt, hogy a verbális, szintaktikai és versformai ismétlödések, illetve variációk hogyan veszik át a trópusok jelentésteremtő funkcióját a költeményben. Ennek részeként ugyancsak fontos az, hogy a Puskin-vers a jelent (a versben feltáruló jelenbeli élménykaraktert, amely a megszólított nőhöz intézett szavak intonációját dominánsan meghatározza) a múltra történő emlékezéssel helyettesíti be: „a múlt idő ellenére a költemény lírai témájában semmi sem látszik lezártnak. [...] Semmi sincs befejezve, sőt a befejezett szemléletet maga a költő is kétségessé teszi a de ellentétes kötőszó után következő jelenidő tagadásával is [nem akarom], és a költői felszólítás eszközével is" (Jakobson 1968, 270). Ez ugyancsak jelentős líratörténeti esemény, mert ettől kezdve válik a szerelmi költészet igazán szerves részévé az, hogy az élmény helyére odaáll az élmény emléke (ehhez hasonló még az 1925-ös ***hoz címü, „Emlékszem még a pillanatra...” kezdetű vers is), amely a hiány alakzatával teszi elmúlhatatlanná, lezárhatatlanná és befejezhetetlenné a szerelmet (ez a magyar lírában Vajdánál ${ }^{2}$ lesz uralkodóvá). S éppen az „illó látomásra” és a „céltalan vágyra” (Puskin 1964, 150) történő emlékezés problémája miatt a versnyelvi beszédmódot átformálja egyfajta narrativitás, amely egy potenciálisan hosszan elmondható történet vázlatát süríti bele nyolc sorba, s teszi így többértelművé a szöveget (vö. Verč 2016, 301-310).

A Puskin-vers szerkezeti felépítése úgy segít jobban megérteni az Ábel és Eszter regényi konfigurációjának versszerủ vonásait, hogy rávilágít a próza-

\footnotetext{
2 „A Gina emléke ciklus címe például pontosan kifejezi a megszólított másik lénynek az emlékben élő fiktivitását és a beszélő memorizáló hozzáállását."Vö. Eisemann 2010, 162.
} 
mü bizonyos poétikai súlypontjaira. Ahogy a Puskin-vers két mondatát sajátos költöi szemantikai viszonyba állítja a grammatikai paralelizmusok sora, úgy a Gárdonyi-regény többértelmüségét is mindenekelőtt az egymás után állított szituációk szüzsés felépítésének morfológiai hasonlósága, variációs ismétlése élteti. Nemcsak az időbeliség szintagmatikus rendje füzi össze a cselekményképző szituációkat, hanem egy olyan paradigmatikus rend is, amely az egymás után sorolt szituációkat egytől egyig visszavezeti egy alaphatárhelyzetre - az összes elkülöníthető cselekményszekvencia ugyanarra a kompozíciós vázra épül (eltérő helyszínekkel és részletekkel). Továbbá, ahogy a Puskin-vers a megszólalás jelen pillanatát a múltra történő emlékezéssel tölti ki, s így egyfelől a lezárhatatlanságot, másfelől pedig azt állítja, hogy a jelenlét módja nem más, mint a szerelem emléke, úgy az Új Időkben olvasható Gárdonyi-regény is a befejez(het)etlenséget tanúsítja a történetet le nem záró végződéssel, illetve azáltal, hogy a szerelem emlékének hajszolásába kényszeríti a főszereplőket:

Nem az az ötlet vonzotta be [Ábelt a szervita templomba], hogy Esztert itt találja, csak Eszternek az emléke. Hányszor ültek ők itt ketten, szótlanul egymásra nem nézve, csupán azért az érzésért, hogy egymás mellett vannak. Az idő lerombolja az érzéseket. Ábel azt kereste: mi maradt belölük? (Gárdonyi 1962, 100.)

Elmúlt az a lázas idő, mikor a holdfényben gyönyörüségtől dideregtünk, mikor egymás karjába borulva sírdogáltunk, hogy a sors milyen kegyetlen. [...] A lázunk elmúlt, Ábel, és te még mindig nem akarod józanul felfogni az életet (Gárdonyi 1962, 110).

Csak olyan volt már neki [Ábelnek Eszter], mint egy elmúlt édes emlék, amely havonkint egyszer-kétszer megjelenik, mint valami visszatérő álom (Gárdonyi 1962, 138).

Egy korán leszállott téli estén Eszter fehérbe öltözött. A mély gyász ideje úgyis rég letelt már, és ő arra gondolt, mennyire tetszett Ábelnak azon a hajnalon, amikor fehérbe öltözötten nézte a nap felkeltét. A ruhát meglocsolta szegfüparfümmel; a haját egycsomóba kötötte, mint akkor (Gárdonyi 1962, 145).

A regény tehát a szerelem emlékét rekonstruálja egy narratívában, azaz a személytörténetbe való betagolása révén. Minden fejezet újabb kísérletet jelent az emléknyomok és a jelenben történendők összekomponálására, miáltal az „epekedés dala” a személytörténetek elbeszélésévé transzformálódik. Eközben a szerelemről alkotott emlékképek átírására is sor kerül a prózanyelv 
közegében azáltal, hogy a találkozások jelenbeli tapasztalatának (ti. a lehetetlenségnek [vö. Gárdonyi 1962, 45]) a megfogalmazása felülírja a megszépített emlékképek fikcióit. Így aztán a Gárdonyi-regény valójában a Puskin-versben feltárt (a fentiekben tömören jellemzett) ellentmondásokkal teli megnyilatkozás-helyzethez hasonló létszituáció által magába sürített élettörténet(ek) szinte végtelenségig elnyújtható narratív kibontásává válik. Máshogy megfogalmazva: a Gárdonyi-regény egy olyan lezárhatatlan történetet mond el, amely teljes egészében visszavezethető egyetlen különös szerelmi megnyilatkozás-helyzetre, összesủríthető egyetlen megszólalásba. Az író később kifejtett prózapoétikai megfontolásaiban így fogalmazza meg ezt az íráselvet: „,a téma próbája: a tartalom egy nagy ellentézises mondatba foglalható össze..." (Gárdonyi 1974, 61), „ha egy mondatba foglalod össze a témádat, a mondatnak nagy ellentézisnek kell lennie" (Gárdonyi 1974, 84). Ilyesmit fedezhetünk fel Eszter és Ábel bizonyos megnyilatkozásaiban. Különös, hogy a két szerelmes föszereplö ilyen mondatok kiejtésére képes: „keresek neked valami jóravaló leányt” (Gárdonyi 1962, 109), „,hát elveszem, mert te akarod, Eszter” (Gárdonyi 1962, 114), ,,igazán hálára köteleztél, hogy megházasítottál” (Gárdonyi 1962, 117), „bizony Eszterkém, férjhez kellene menned” (Gárdonyi 1962, 146), „férjhez kellene menned, hiszen még fiatal vagy, szép is vagy. De kihez?" (Gárdonyi 1962, 147). Ezek a mondatok mind-mind rímelnek az „Ég adja, hogy szeresse más is így" verssorra. Úgy tünik tehát, hogy a Gárdonyi-regény tétjét pontosan süríti össze a Puskin-mü két versnyelvileg felépített mondata, s az abba integrált létszituáció. Így talán érthetőbb már, milyen is lehet az dal, amelynek szövegét az Ábel és Eszter mondja el.

De hogy még világosabbá váljon a prózamủ versnyelvi megalapozottsága, érdemes még valamire felhívni a figyelmet. A Gárdonyi-regény talán legszebben kidolgozott része a 10. fejezet (Gárdonyi 1962, 93-102). Ebben arról olvashatunk, hogy a megházasodott és várandós Esztertöl hogyan próbál sikertelenül eltávolodni Ábel, aki számára lehetőség nyílik arra (az édesanya halála után váratlanul előkerülő örökség anyagi támogatásával), hogy külföldön fejezze be tanulmányait. Ábel Berlinbe utazik, ahol elvégzi a felső gimnáziumot, és elkezdi egyetemi filológiai tanulmányait. Esztert nem tudja kiverni fejéből; a legjobbakat kívánja neki férje és kislánya mellett, de azért némi féltékenységgel és irigységgel gondol rájuk. Az asszony gyermekének megszületéséig leveleznek, de utána négy évig semmit sem tudnak egymásról (a regény története 1860 áprilisától 1867 elejéig tart, a berlini időszak 1861 novemberétől 1865 tavaszáig terjed). Eközben Ábel mindennap így gondol Eszterre: 


\section{Szerette volna látni, látni (Gárdonyi 1962, 94).}

Minden emléke föléledt.

Látnia kell Esztert, még egyszer látnia, és hallania még egyszer, amint az a kellemes csupa-érzés hang azt mondja: Ábelkám.

Sokszor felébredt benne ez az érzés, de így, mint most, soha. Akármivel foglalkozott, mindig Eszter képe lebegett előtte. Látta a mozdulatait, a fejetartását, a mosolygását, a haját, a kezének kedves feléje nyújtását, és leginkább a szemét, azt a mosolygó bizalmas nézést, amely tavaszi verőfényként sugárzott bele a szíve mélyébe (Gárdonyi 1962, 95).

Nem látom, nem látom talán soha többé (Gárdonyi 1962, 95).

Csak egy kicsit szeretné látni, csak a fejét hátulról, csak a kezét, amint az imádságos könyvet kinyitja. Csak úgy szeretné látni, mint azt a kardot, csákót, falovat, amellyel gyermekkorában játszott. Csak megnézné, de már nem játszana vele (Gárdonyi 1962, 99).

Eszter és a szerelem élménye álomszerü vízióként, „mint csodás / Szépség eszményi fényalakja, / Mint lenge, illó látomás" (Puskin 1964, 150), vagyis egy, az emlékezet által fenntartott és prózában előadott vizuális benyomás látásaként és a látásban érvényre jutó akarásként jelenik meg Ábel berlini évei alatt. Az emlékezés és a látás akarása, az asszonytól történő végső elbúcsúzásra tett kísérlet, a legköltőibb módon az utolsóként idézett bekezdésben fejeződik ki. Ezt a bekezdést Gárdonyi úgy írta meg, mint egy verset: a gondolaritmus uralja a prózaszöveg felépítését. Hogy ez az érvelés meggyőzőbb legyen, felidézek egy verset, amely ugyanerre a gondolatritmusra épül (ennek megfelelően torzítom el az alábbi idézet során az egybeírt versszöveg tördelését is). Filológiai bizonyítékaim nincsenek, de a szövegösszefüggés alapján nem nehéz kimutatni a talán nem véletlen összefüggést a Gárdonyi-bekezdés és József Attila híres, 1936-os Az a szép, régi asszony címü költeménye között: ${ }^{3}$

Azt a szép, régi asszonyt szeretném látni ismét, akiben elzárkózott a tünde, lágy kedvesség, aki a mezők mellett, ha sétálgattunk hárman, vidáman s komolyan lépett a könnyü sárban, aki ha rám tekintett, nem tudtam nem remegni, azt a szép, régi asszonyt szeretném nem szeretni.

\footnotetext{
${ }^{3}$ A versről bővebben lásd Bókay 1990, 656-668, illetve Bókay 2004, 159-176.
} 
Csak látni szeretném öt, nincs vele semmi tervem, napozva, álmodozva amint ott ül a kertben s mint ő maga, becsukva egy könyv van a kezében s körül nagy, tömött lombok zúgnak az őszi szélben.

EInézném, amint egyszer csak tétovázva, lassan, mint aki gondol egyet a susogó lugasban, föláll és szertepillant és hirtelen megindul és nekivág az útnak, mely a kert bokrain túl ott lappang, elvezetni a távolokon által, két oldalán a búcsút integető fákkal.

Csak úgy szeretném látni, mint holt anyját a gyermek, azt a szép, régi asszonyt, amint a fényben elmegy.

József Attila asszonybúcsúztató verse sok tekintetben megfeleltethető Ábel belső beszédének. ${ }^{4} \mathrm{~A}$, látni szeretném” és a „nézném” kifejezés variációs ismétlődéseire épülő mondatok ugyanúgy határozzák meg a regénybeli bekezdést (sőt, a teljes 10 . fejezetet), mint a vers szerkezetét. És nemcsak hogy a gondolatritmus teljesen azonos a prózai bekezdésben (sőt, talán az egész 10. fejezetben) és a versben, hanem még a költemény egyéb építőegységei is megfeleltethetők a regény kulcsmotívumainak. Az asszony „tünde, lágy kedvessége” megfeleltethető Eszternek a regény 1. fejezetében olvasható képével, azzal, ahogyan az esti séták során a holddal különös kapcsolatba lépve átlényegül, és tündérként vagy nimfaként mezítláb táncol a harmatos éjjeli mezőn (Gárdonyi 1962, 28-33). A „mezők mellett, ha sétálgattunk hárman” kifejezés által felvázolt tér azonos azzal az esti zugligeti és lipótmezei világgal, amelyben Ábel és Eszter együtt andalog esténként a regény legelején (a harmadik fél Eszter jegyesének árnyékaként azonosítható be). A „napozás” és az a „fény”, amely körülveszi a versben az asszonyt, megfeleltethető a regénykezdés legfontosabb pillanatának, amelyben Ábel és Eszter a felkelő napot csodálva „nézte, miként piroslik az ég, miként villan föl az első sugár. De Ábel most is csak Eszter arcát nézte. Amint rásütött a nap, narancsszínü fénnyel öntötte el az arcát" (Gárdonyi 1962, 33). Ez az a tökéletes pillanat, amelyet mindkét főszereplő próbál visszahozni a regény során. A versbeli kert megfeleltethető Eszterék lipótmezei nyaralója kertjének. A „mint ő maga, becsukva egy könyv van a kezében” sor is rímel a vizsgált bekezdésben olvasható imádságoskönyvre, illetve arra, ahogyan Eszter

${ }^{4}$ A költészet és belső beszéd összefüggéséről bővebben lásd Vigotszkij 1971, 325-395. 
önmagáról beszél egy helyen: „,hiába most már: olyan vagyok, mint a könyvböl kiszakított lap, amelyet más könyvbe ragasztanak bele" (Gárdonyi 1962, 86). Végül pedig még a vers végén elökerülö gyermeki viszonyulás is tetten érhető a regényből idézett bekezdésnek a gyermekkori játékszerekről szóló szavaiban. Úgy tünik tehát, mintha a vers éppen abban az emlékezetben létező és immár álomszerüen látomásos közegben búcsúztatná el az asszonyt, ahogy Eszter él Ábel gondolataiban, és ahogy Ábel próbál belső beszédében búcsút venni a férjes asszonytól, pontosabban szólva annak régi, képzeletben megmutatkozó képétől. Akár érvényes feltételezés az, hogy József Attila verse nem más, mint Ábel éneke, akár nem, mindenesetre a költemény pontosan mutat rá a regényszöveg versszerủ alapstruktúrájára.

Puskin és József Attila verse kiemeli, hogy a szerelmet tematizáló költészet nem (pusztán csak) megverseli a szerelmi élményt, hanem inkább kutatja a szerelem szó jelentését. Puskin verse egy különös irányba tereli a szerelem szó értelmi körét: a költői szemantikai innováció a szó jelentésének részévé avatja azt a diszpozíciót, amelyben az ember képes meghaladni saját körét, $\mathrm{s}$ eljut odáig, hogy az igazi szeretés magába foglalja azt az akaratot is, „hogy szeresse más is így”. József Attila verse az akarást („,szeretném”) és a szeretést helyezi feszültségbe. Mindkét viszonyulást a szeret hangsor nevezi meg, s egy önellentmondó, de jelentésteli kifejezés füzi össze: „szeretném nem szeretni”. A költemény a „szeretném nem szeretni” diszpozíciójának felépítésével pedig valójában a szeretés egy eredeti megélését hozza létre. Az egész vers a „szeretném látni” kifejezés jelentéskörét tágítja egészen odáig, ameddig ebben az akaratban sikerül feltárni a távolságon át létező s a másikat elbocsátani is képes szeretetet.

A továbbiakban azt kell körüljárnia a szövegértelmezésnek, hogy Gárdonyi regényében hogyan formálódik a szerelem szó szemantikai megújítása a prózanyelvi környezetben.

\section{A szeretés prózanyelvi alakmásai}

A regény férfi főszereplöjének cselekvésmódját alapvetően meghatározó tételmondat az alábbi: ,gondolkozzunk csak nyugodtan!” (Gárdonyi 1962, $11,12,13,38,39,40,67,101,114,134,147)$. Azért kiemelkedően fontos ez a kifejezés, mert ismétlődésének elburjánzása hívja fel a figyelmet arra, hogy a regény az események időbeli előrehaladásának előadása során folyamatosan visszatér egy olyan történetképző sémához, amely az eseményeket indukáló és körülvevő eltérő szituációk megszerkesztéséhez mindig ugyanazt a határ- 
helyzet-modellt használja fel. A regény 1. fejezete arról szól, hogyan talál rá Ábel Eszterre, hogyan hívja fel magára a figyelmet, hogyan vallanak szerelmet - szinte azonnal - egymásnak, s hogyan sikerül olyan perceket lopni, amelyekben együtt lehetnek, de amelyeket már az első pillanattól kezdve megkeserít az Eszter által bevallott tény: „már el vagyok jegyezve” (Gárdonyi 1962, 22). A további 14 fejezet pedig arról szól, hogyan következnek egymás után olyan szituációk, amelyekben újra átélik ugyanezt a megoldhatatlan helyzetet. A szöveg összesen 13 olyan szituációt (vagy szituációsorozatot) gyüjt össze, amelyben Ábel és Eszter eltérő közegekben megpróbál közel férkőzni egymáshoz, azonban gyorsan kiderül, hogy „,mindig köztük áll valaki, mindig köztük van egy elválasztó kéz" (Gárdonyi 1962, 104). Prózapoétikai szempontból az a fö kérdés, hogy ugyanazon határhelyzet eltérő variációinak egymásutánjából hogyan lesz egységes regényszöveg. Ennek az egységképzésnek vajmi kevés köze van az Ábel és Eszter esetében a narrációhoz. Az elbeszélő diszkurzus eljárásai csak annyit tudnak elérni, hogy kiválogatják, majd egymás után helyezik az alaphatárhelyzet variációit és a kényszerszituációkra adott ismétlődő és egyenértékü szereplői cselekvésreakciókat (Ábel esetében: „gondolkodjunk csak nyugodtan"; Eszter esetében: a tehetetlenséget megtestesítő pótcselekvések [tánc, sírás, ajtóbecsapás stb.]). Mindezek szelektálása, kombinálása és szüzsés egymás után helyezése önmagában - ahogy arra a fentiekben rávilágítottam - egy versszerủ gondolatritmust testesít meg: egyfajta ritmikus narrációt képez. A regény esetében azonban mégiscsak prózáról van szó, amely más szövegvilágot létesít, mint a (gondolat)ritmusra épülő vers. Gárdonyi a prózanyelv sajátos eljárásával, ti. a részletezés diszkurzusának alakmásteremtő (kon)figurációjával teremt a sorozatból egységes szövegvilágot. A részletezés ${ }^{5}$ a narráció cselekményképző eljárásait kiegészítve hoz létre - a mondatok szintjén - egy egységes prózai szemioszférát; ${ }^{6}$ az alakmásképzés ${ }^{7}$ pedig a részletezés eljárásaira alapozva hoz létre - a szöveg szintjén - egy egységes diszkurzív szemantikai világot, amelyben ugyanazon határhelyzet különbözö megvalósulásainak eltérő (de egymásnak megfeleltethető) alkotóelemei jelentésbeli ekvivalenciába kerülnek.

\footnotetext{
${ }^{5}$ A regényi prózának a részletezés vagy „détalizáció” szempontjából megragadható specifikumáról bővebben lásd Kemény 1971, 191-213. Ennek jelentőségéröl Gárdonyinál lásd Kovács 2013, 51-81.

${ }^{6}$ A szemioszféra fogalmáról bővebben lásd Lotman 1994, 119-185, 186-210; Lotman 2002, 89-118.

${ }^{7}$ Az alakmásképzés prózanyelvi jelentőségéről bővebben lásd Kovács 2019, 321-337.
} 
A regény cselekményét meghatározó alap-határhelyzet 13 variációjában minden egyes esetben pontosan felismerhető egy-egy kézzelfogható referenciális elem (tárgy vagy személy), amely a megnevezés és a cselekménybeiktatás során határmetaforává válik. És minden szituációban feltűnik egy-egy szimbolizálódó cselekvéstér is, amely a müvészei próza diszkurzív rendjében alakmási jelleget ölt fel. A különböző tárgyak megnevezésére épülő határmetaforák a két főszereplő elválasztottságát jelölik meg, az eltérő cselekvésterek verbális felépítése pedig a határ áttörésére irányuló főszereplői akarat alakmásaivá válnak - miközben létrehozzák a szöveg egységes világát is. Vizsgáljuk meg előbb a határtrópusokat, utána a szeretés metaforikus értelmú alakmásait!

Az 1. szituáció az, amelyben Ábel megpillantja Esztert a Lánchídtól a Városligetig vezető omnibuszútvonalon. Ami megakadályozza a lány megszólítását, az az anya szigorú tekintete. A 2. szituációsorban Ábel napról napra, hétről hétre megjelenik Eszterék belvárosi háza előtt, s igyekszik felhívni magára a figyelmet. A lány ablaka testesíti meg közöttük a határt. A 3. szituációsor Eszterék lipótmezei nyaralójának kertjében játszódik. A két főszereplő már beszélget, de a kerítés és a kapu elválasztja őket. A 4. szituációsorban lehetünk tanúi a zugligeti sétáknak, amelyek során az első érintések és csókok megtörténnek, de ekkor derül ki, hogy az „apa akarata” (Gárdonyi 1962, 22), vagyis az eljegyzés megakadályozza Ábel és Eszter viszonyának kibomlását. Az 5. szituáció feszült helyzetét az adja, hogy a Kardos Eszter és Eördögh Károly családja közötti szerződés eredményeként megvalósuló esküvő miatt Ábelnek el kellene távolodnia Esztertől. A 6. szituációsor sajátossága az, hogy Ábelnek és Eszternek csak teljes titkokban szabad találkoznia. Ekkor Eszter házassága, illetve az anyós gyanakvó húga zavarja a két főszereplő együttlétét. A 7. szituációban Eszternek sikerül kikerülnie a gyanakvó tekinteteket, így újra a Zugligetben találkozhat Ábellel. Itt igyekeznek újra átélni az egy évvel korábbi napfelkeltekor megélt élményt, de Eszter asszonystátusza megakadályozza a múlt maradéktalan megismétlését. A 8. szituációsorban Ábel és Eszter a Múzeumkertben találkozgat, de megkeseríti az együttlétet az, hogy az asszonynak folyton az otthoni gondokkal kell viaskodnia, $\mathrm{s}$ állandóan erről panaszkodik. A 9. szituációsorban már sokat kockáztat Eszter a kapcsolatuk fenntartása érdekében, merthogy otthonában látogatja meg Ábelt, ámde a férfi súlyos tüdőgyulladása nem engedi meg még csak a szóbeli érintkezést sem. A 10. szituációsor tart az elbeszélt idő szempontjából a leghosszabb ideig: Ábel 4 éven át Berlinben tanul. Az időszak elején Eszter terhessége, majd a tér és az idő választja el a két föszereplőt (,jobb, ha lassankint közéjük száll az idő, s felejtik egymást" [Gárdonyi 1962, 94]). Ábel hazatérése után következik a 
11. szituációsor: 4 év után Ábel odaáll Eszter elé, aki a karjaiba ájul, majd az ezt követő időszakban újra találkozgatnak városligeti séták során. Ekkor Eszter gyermeke, Irénke áll közöttük élö tilalomfaként. A 12. szituációsor azt szüli, hogy Eszter feleséget akar keresni Ábelnek; Ábel meg is házasodik, de közben - nagyobb megszakításokkal - továbbra is együtt sétálgat Eszterrel és a mindig jelen levő Irénkével. Ezeket a találkozókat Ábel feleségének gyanakvása árnyékolja be. Végül, a 13. szituációsor Eszter megözvegyülésével és Ábel fiának megszületésével veszi kezdetét. A találkozók előbb rendszertelen időközökben, majd újra rendezetten követik egymást így aztán „,[Eszter] érezte, hogy [Ábel] az övé, mint régen, azokon a holdas, harmatos éjszakákon, azokon a titkos találkozásokon. Csak a gyászruha van még köztük, meg talán kis ideig még a bölcső" (Gárdonyi 1962, 144). Miután egy ilyen találkozón, Eszter lakásán Ábel azt javasolja, hogy közösen keressenek új férjet, az asszony felpattan, és becsapja maga mögött a szobaajtót. Ezzel a képpel zárul a regény - a bezárt ajtó a regény összes szituációját jellemző határhelyzet felszámolhatatlanságának metaforikus jeleként áll a szöveg végén.

Amint látjuk tehát, az egymás után sorolt azonos morfológiai felépítéssel bíró szüzsés szekvenciák kiemelnek olyan szövegelemeket, amelyek azonos funkciót töltenek be a határhelyzet-variációkban, s így végül is szemantikailag ekvivalensekké válnak. A történet szintjén megragadható teljesen különálló tárgyi elemek, vagyis Eszter édesanyjának szigorú tekintete, az ablak, a kerítés és a kertkapu, az apa akarata, az eljegyzés, az esküvő, Eszter anyósának húga, az asszonyság, a családi otthon gondja, a tüdőgyulladás, a terhesség, a Budapest-Berlin távolság, négy év ideje, Eszter gyermeke, Ábel felesége, Eszter gyászruhája és Ábel fiának bölcsője s végül a bezárt szobaajtó mindmind egymás megfelelőivé válnak a regényi konfigurációban (vagyis a szöveg szintjén). Határmetaforákká válnak - egy olyan trópusgyüjteménnyé, amely az eseménysort egy közös (tehát egyfelöl egy középpont felé gravitáló) és mindig megújuló (tehát másfelől táguló) szemantikai egység alá tudja rendelni. A szerelem gondját így nemcsak az olyan archetipikus tárgyi szimbólumok jelölik meg, mint az ajtó, ablak, kapu és kerítés, hanem az olyan elvont fogalmak is, mint az apai örökség, az eljegyzés, az esküvő, a házasság, az asszonyság, az otthon, a rokonság, a térbeli és az időbeli távolság, sőt az olyan különös tényezők, mint a terhesség (és az apaság), a tüdőgyulladás (betegség), a gyászruha és a bölcső is. Ebben a költői alkotásban minden, ami a hétköznapi tapasztalataink szerint a tárgyak, a kulturális tényezők és az egzisztenciális tapasztalatok szintjén össze tudja kötni az embereket, éppen hogy a két szerelmes főszereplő együttlétének akadályává válik. A szereplők nem ezekért, hanem ezek ellenére 
szeretik egymást. Ezzel Gárdonyi teljesen kicsavarja müvében a szerelemre utaló képek és sablonok szokásrendi, mindennapi logikáját, s éppen arra mutat rá, hogy a szeretés tevékenysége és a szerelem szó mindezeken túl, sőt, talán mindezek ellenére (is) létezö összeköttetést jelent. S az egymásrautaltságnak ezt a fokát a regény kizárólag azzal tudja előállítani és feltárni, hogy a szüzsés funkció-odatulajdonítás és a költői jelentésalkotás segítségével a sok különnemü - gyakran egymásnak ellentmondó - tényezőt egy szemantikai körbe vonva létrehozza a mü egységes szövegvilágát. ${ }^{8}$

Azonban nemcsak a határmetaforák egységképző ereje által kifejtett szemantikai folyamatok sora szavatolja a szöveg világának egységességét. Legalább ennyire fontos az is, hogy milyen módon próbálja Ábel és Eszter keresztültörni a szituációsorozatok által kiterjesztett alaphatárhelyzet „falait”. Talán éppen itt lehet majd rábukkanni arra, hogy Gárdonyi regénye mit is ért a szeretés szó alatt. Az 1. szituációban a két főszereplő közötti határt megtestesítő anyai védelmet csak egy dolog tudja áttörni - a tekintetek játéka: ,a szőke fiatalembernek rajta ragadt a tekintete” (Gárdonyi 1962, 8), „szinte áhítattal nézett reá” (Gárdonyi 1962, 8), ,jámbor kék szeme ábrándosan csüggött a leányon" (Gárdonyi 1962, 8), ,a fiatalember pillogva nézte” (Gárdonyi 1962, 9), „szinte falta a szemével” (Gárdonyi 1962, 9). Az Eszterre felfigyelő Ábel azonnal át is veszi a lány arcszínét: „mintha az ő arcára szállott volna át a leány pirossága, megszínesedett” (Gárdonyi 1962,8). A 2. szituációsorban a két szereplőt elválasztó ablakon keresztül (s túl a tekintetek továbbfolytatódó játékán) az az „egy szál piros rózsa” (Gárdonyi 1962, 10) épít kapcsolatot, amelyet Ábel odalop az ablakpárkányon álló virágtartóba. A 3. szituációsorban a kerítést a szó, az elfogulatlan beszéd és a kezek érintése képes ,áttörni”. A 4. szituációsorban a már együtt sétálgató főszereplőket mindenekelőtt a krisztinavárosi templom szenteltvize kapcsolja össze: „a leány belemártotta ujja hegyét a szentelt vízbe, és odatartotta Ábelnek. Az ujjuk érintkezett. Keresztet vetettek" (Gárdonyi 1962, 25). Majd a holdfényben úszó mezők és az első csókok hozzák közelebb őket egymáshoz - itt jön létre az a látvány, amely később a szerelem és a szerelmes emlék víziójává

\footnotetext{
${ }^{8}$ Ez a szövegvilág magába foglalja a XIX. század utolsó harmadában újjáépülő főváros szemioszférájának bizonyos, verbálisan rekonstruálható képét is. Talán nem véletlen, hogy a történet közvetlenül Pest, Buda és Óbuda egyesítése (1873) előtti időszakban játszódik - ez is rávilágít arra az egységben rejlő szétválasztottságra, vagy a szétválasztottság ellenére működő szimbiózisra, amelyben Ábel és Eszter él. A belvárosnak a Lánchídtól a Városligetig terjedő területét (Akadémia, Nemzeti Múzeum, Király utca, Városligeti fasor, nevezetes belvárosi utcák és épületek stb.), illetve a budai oldal hegyekkel, erdőkkel, mezőkkel tagolt táját besétálja a két főszereplö, így ezek a vidékek a regényszöveg világában a páratlan pár titkos és tiltott szerelmének térbeli kiterjesztéseivé válnak.
} 
formálódik. Az 5. szituációban egy később is visszatérő tényező, a levél kapcsolja össze Ábelt a megházasodó Eszterrel. A 6. szituációsorban részben Ábel munkahelye, a könyvkereskedés üzlethelyisége ad teret annak, hogy Eszter újra felvegye a személyes kapcsolatot Ábellel, miközben szerelmes regényeket és szép novellákat tartalmazó folyóiratokat vásárol. De nagyobb részben a belvárosi Szent Anna-templom, vagyis a szervita templom ad lehetöséget a találkozásra; ide bújnak el a föszereplők Eszter rokonainak gyanakvó tekintete elöl: ,ilyenkor a két kéz melegsége édes ellanyhulással áramlott össze. És ez az érzés abban a tömjénillatos homályban olyan földfeletti volt" (Gárdonyi 1962, 46). A 7. szituációban Ábel és Eszter visszatér a Zugligetbe, és visszaemlékezik az egy évvel korábbi pillanatra. Ekkor az emlékezés, a régi szerelem álma („Mit is mond Kalderon? »Az élet álom «" [Gárdonyi 1962, 55]), illetve az egy év után megismételt csók („látod, ez szép, hogy mióta asszony vagyok, nem csókoltál meg, csak ma" [Gárdonyi 1962, 56]) - egyszóval: a tökéletes pillanatra irányuló emlékezés köti össze a fószereplöket. Azt, hogy innentől kezdve nem is annyira szerelem, hanem a szerelem emléke élteti viszonyukat, csak megerősíti, hogy a 8. szituációsortól kezdve már másként nevezik meg kapcsolatukat: „gyöngéd testvéri érzés" (Gárdonyi 1962, 66) köti össze öket. A 9. szituációsorban egyetlen kommunikációs kapcsolat füzi össze a lázban fekvő öntudatlan Ábelt Eszterrel - a betegápolás. A berlini éveket felölelő 10. szituációsorban részben a levél tér vissza összekötő elemként, de rövid idő után már csak Ábel víziói és a látás akarása tartja életben a viszonyt. A 11. szituációsorban a Városligeti fasor és a fiáker belső tere ad lehetőséget arra, hogy Eszter kislányának jelenléte ellenére is bizalmas viszony épüljön ki újra a két főszereplő között. Ábel esküvője után, a 12. szituációsorban ismét csak a régi időkre irányuló emlékezés kötheti össze az egyre ritkábban és már a családi körben is találkozó főszereplőket:

- Tudod-e mi jutott eszembe, amikor ott ültél a kályha elött?

- Micsoda, Ábelkám?

- A tüz fénye rád piroslott. És ahogy ott ültél fehér kabátban, olyan volt az arcod, mint azon a hajnalon, mikor a sziklán állva néztük a napot.

Eszter lehunyta a szemét.

- Mire gondolsz? - kérdezte Ábel.

- Arra a boldog időre - felelte Eszter sóhajtva (Gárdonyi 1962, 127).

Ábel fiának megszületése, illetve Eszter megözvegyülése után is már csak az álomszerü emlékezés marad: „olyan volt már neki, mint egy elmúlt édes emlék, amely havonkint egyszer-kétszer megjelenik, mint valami visszatérö álom" (Gárdonyi 1962, 138). 
A történetalkotó szituációk által kiterjesztett alaphatárhelyzet „falainak” áttörésére irányuló föszereplői törekvések felsorolásából kidomborodik az, hogy a Gárdonyi-regény miként hozza létre sajátos elgondolását a szeretésröl. A tekintet és a pillantás, egy szál rózsa (és egyéb virág), a szó, a kezek érintkezése, a szenteltvíz, a holdfény, a felkelő nap fénye, a csók, a levél, a templom, az ápolás, a sétatér és (mindenekelőtt) az emlékezés az, amelynek segítségével a két főszereplő megpróbál kitörni a határhelyzetből. A motívumsor egy nagy szemantikai konfigurációban olvad össze - egyfelöl ez szavatolja a szövegvilág egységességének kialakulását, másfelől ez teremti meg a szeretés megcselekvésének alakmásait is a müben. $\mathrm{S}$ ez a szemantikai folyamat következetesen vezet a materiálistól az immateriális felé. A regényben mindig a legelső pillantást próbálják felidézni a találkozó tekintetek; illetve a holdfény és a felkelő nap fényének nemhogy a látványa, hanem a látvány emléke $\mathrm{s}$ a látás akarása válik a legfontosabb interperszonális összekötő jeggyé. A szerelem születését megjelölő virágoknak a rózsától a liliomon és a jázminon át a hársfavirágig húzódó tömege áttranszformálódik Eszter számtalanszor megemlített szegfüillatába (Gárdonyi 1962, 17, 19, 43, 51, 96, 123, 139, 145), amely mindig felidézi a mezők világát. Ebben a regényben az érintésnek semmi köze a szeretői érintéshez. A krisztinavárosi templomban a szenteltvizet átnyújtó ujjak érintkezése és a szervita templomi találkozások során a tömjénillatban összefonódó kezek melege hangsúlyosan hívja fel a figyelmet arra, hogy Ábel és Eszter esetleges fizikai érintkezése (még az emlékeztető funkcióval felruházott csók is) pusztán csak az immateriális összeköttetés materiális jele. Az élő és az írott szó sem elsősorban a kézzelfogható jelenlét formája a müben. Ebben a regényben a szónak csak nagyon kevés köze van a szerelmi vallomásnak ahhoz a nyelvéhez, amelyben meg is történik a szerelem; ${ }^{9}$ sokkal inkább az emlékező szó, vagyis a múltat a jelenben verbálisan újraalkotni törekvő elbeszélő megnyilatkozás kapcsolódik össze a szeretés szavával. A levél, a fiáker, a belvárost a Ligettel összekötő Városligeti fasor, a templom, de még a másik otthona is a találkozások olyan tereként funkcionál a müben, amely a két főszereplő számára se kiindulópontot, se célállomást nem jelent, hanem mindig valamilyen átkelöhelyként, átmenetként jelenik meg, s így elveszítve fizikai jellemzőit a végeérhetetlen úton levés szférájává alakul. Mindebből kirajzolódik az a szemantikai innováció, amelyet a regényszöveg visz véghez

\footnotetext{
${ }^{9}$ Vö.: „Miket beszélget holdvilágnál két szerelmes fiatal? Valóban ha leírnák, elbámulna az ember, mennyi üres ostobaság. De az, aki beszéli, annak a világ legérdekesebb olvasmánya lenne. Mert a sorok között érezné két szívnek a dobogását, a szaggatott mondatokban a mosolyt, a fejrázást, a kézszorítást, a sóhajtást; a pontoknál a csókot” (Gárdonyi 1962, 32).
} 
a szeretés szóban. Úgy fest, mintha a regény tagadná, hogy a szerelem jelen lehet. Pontosabban szólva: egyetlen pillanatban van jelen, az átélése egyetlen pillanatig tart. Ezt jelöli meg a felkelö nap fényében megpillantott arc vagy a szenteltvízbe mártott ujjak pillanatnyi találkozása. Így a szerelem eseményszerü - ráadásul a régmúlt egy eseménye. A szeretés azonban folyamat. Nem más, mint folyamatos emlékezés az elmúlt, a régen elmúlt pillanatra egyfelöl; másfelől pedig végcél nélküli folyamatos úton levés (a regényben: séta), amelynek hajtóereje a pillanat újraalkotására irányuló akarat. Ebben ragadja meg a szöveg a szeretés szakralitását is (amely olyannyira fontos aspektusa a münek): az az akarat, amely távolról újra látni szeretné az elmúlt pillanatot, szakrális szintre emeli a régi bekövetkezés vagy megtörténés eseményét. Nem plátói szerelemről és nem is küzdelmes lovagi szerelemről van itt szó. A szeretés akarását, az akarás hosszú folyamatát, a folyamat állandó újrakezdését megkövetelő nehézségeit állítja elénk a regény. Gárdonyi müvében a szeretés a szerelmi esemény emlékét fenntartani és rekonstruálni igyekvő akarat cselekvő megvalósulása.

\section{Irodalom}

Bókay Antal. 1990. József Attila: Az a szép, régi asszony. ItK (5-6): 656-668.

Bókay Antal. 2004. Az anyamodell. In József Attila poétikái. 159-176. Budapest: Gondolat Kiadó.

Eisemann György. 2010. A szerelmi diszkurzus líraisága. In A későromantikus magyar líra. 160-175. Budapest: Ráció Kiadó.

Gárdonyi Géza. É. n. Ábel és Eszter. Budapest: Dante Kiadó.

Gárdonyi Géza. 1962. Ábel és Eszter. In Ábel és Eszter: Kisregények 1905-1913, szerk. Z. Szalai Sándor, Tóth Gyula. 5-147. Budapest: Szépirodalmi Könyvkiadó.

Gárdonyi Géza. 1974. Mesterkönyv. In Titkosnapló, szerk. Z. Szalai Sándor. 51-147. Budapest: Szépirodalmi Könyvkiadó.

Gárdonyi József. 1934. Az éló Gárdonyi II. Budapest: Dante Kiadó.

Jakobson, Roman. 1968. A grammatika poétikája és a poétika grammatikája. In Hangjel-vers, szerk. Fónagy Iván, Szépe György. 258-277. Budapest: Gondolat Kiadó.

Jaspers, Karl. 2008. A határhelyzetek mint conditio humana. In Mi az ember?: Filozófiai gondolkodás mindenkinek. Ford. Körös László. 109-143. Budapest: Katalizátor Könyvkiadó.

Kemény Zsigmond. 1971. Eszmék a regény és a dráma körül. In Élet és irodalom. 191-213. Budapest: Szépirodalmi Könyvkiadó.

Kovács Gábor. 2013. A részlet esztétikuma (Gárdonyi Géza: Az öreg tekintetes). In Egri jubileumok III: „, Agyagedénybe zárt Isten-sugár”: In memoriam Gárdonyi Géza, szerk. Cs. Varga István. 59-81. Budapest: Hungarovox Kiadó. 
Kovács Gábor. 2019. Alakmásképzés a regényben. In Leirás: Elmélet, irodalom, kép, szerk. Hajdú Péter, Kálmán C. György, Mekis D. János, Z. Varga Zoltán. 321-337. Budapest: Reciti.

Lotman, Jurij. 1994. A müvészi tér problémája Gogol prózájában. In Kultúra, szöveg, narráció, szerk. Kovács Árpád, V. Gilbert Edit. 119-185. Pécs: Janus Pannonius Egyetemi Kiadó.

Lotman, Jurij. 1994. Pétervár szimbolikája és a város szemiotikájának problémái. In Kultúra, szöveg, narráció, szerk. Kovács Árpád, V. Gilbert Edit. 186-210. Pécs: Janus Pannonius Egyetemi Kiadó.

Lotman, Jurij. 2002. A szemioszféra. In Kultúra és intellektus, szerk., ford. Szitár Katalin. 89-118. Budapest: Argumentum Kiadó.

Puskin. 1866. Északi fény: Puskin Sándor, Lermontoff Mihály költeményei. Pest: Emich Gusztáv.

Puskin. 1964. Alekszandr Puskin válogatott költöi müvei. Budapest: Európa Könyvkiadó.

Verč, Ivan. 2016. Ja vas ljubil... di A. S. Puškin come narrazione. In Verifiche, Preverjanja, Проверки III. 301-310. Edizioni dell’Universita di Trieste.

Vigotszkij, L. Sz. 1971. A gondolat és a szó. In Gondolkodás és beszéd. 325-395. Budapest: Akadémiai Kiadó.

Z. Szalai Sándor. 1962. Gárdonyi Géza kisregényei. In Ábel és Eszter: Kisregények 1905-1913, szerk. Z. Szalai Sándor, Tóth Gyula. 479-492. Budapest: Szépirodalmi Könyvkiadó.

\section{VARIATIONS ON A BOUNDARY SITUATION Géza Gárdonyi: Ábel és Eszter}

The main problem of the innovations of Géza Gárdonyi's prose in the 1910's is the following: "if you want to write a novel, you should begin by writing it in a 1/10 reduced form, a single scene short story", "one should not design a novel as a novel, but as a short story". And that scene must be highly emotionalized: "a novelist must seek for the character-creator thrill - the trouble, misery, difficulties, and exigencies that distress the character's substance". Gárdonyi's short novels unfold a text from one single boundary situation (created by reductive devices of the short story's prose language) by inventing its antecedents and after-effects. During the writing of Ábel és Eszter in 1905 Gárdonyi had already recognised the productivity of such a technique, but he applied it in another way. In my interpretation I would like to reveal the type of the textual world and existential sense that derives from a work which consists of the variations of one single boundary situation.

Keywords: boundary situation, narrative rhythm, the problem of counterpart, semantic innovation in prose language 


\section{VARIJACIJE PRINUDNOG STANJA \\ Geza Gardonji: Avelj i Estera}

Jedno od temeljnih načela obnovljenog proznog stvaralaštva Gardonjija u drugoj deceniji prošlog veka glasi: ,ako sedneš za pisaći sto sa namerom da napišeš roman, počni tako što ćeš napisati na deseti deo skraćenu verziju, novelu sa jednom scenom“, „ne nameravaj da napišeš roman, već samo novelu“ (Gardonji 1974, 70). Ova scena treba da bude puna napetosti: „,traži uzbuđenje, iz koje izranja karakter. Situaciju, slučaj koji se vrti oko ose nevolje, problema i karaktera“(Gardonji 1974, 77). Forma kratkog romana karakteristična za ovog pisca, iz stvorenog prinudnog stanja, pomoću zgusnutog postupka proznog jezika novele, razrađuje tekst tako što opisuje prethodne događaje a zatim i posledice koje iz njih proizilaze. Tokom pisanja romana Avelj $i$ Estera Gardonji je spoznao delotvornost ove tehnike, ali ju je još primenjivao na drugi način. U radu se analizira kakav tekstualni svet nastaje i kakav se egzistencijalni smisao javlja kada čitavo delo određuju varijacijska ponavljanja istog prinudnog stanja.

Ključne reči: granična stanja, ritam naracije, značenjska obnova proznog jezika 